\title{
歩行者の経路選択性向に関する研究 \\ A STUDY ON PEDESTRIAN'S PREFERENCE IN ROUTE SELECTING
}

\author{
竹 内 伝 史* \\ By Denshi TAKEUCHI
}

\section{1.はじめに}

モータリゼーションの進展と共に都市の街路空間は無 際限に, 自動車の交通のために明け渡されてきた. そし て, 一連の高度経済成長の時期が見直されるようになっ た今日, 都市問題においても, 自動車化した都市交通体 系の諸矛盾が大きな問題として指摘されている.すなわ ち, 交通事故, 交通公害, 大量輸送サービスの低劣化そ して交通渋滞などである.これらは，いずれも大量化し た自動車交通が，都市交通システムを一元的に支配する ことになったことから生ずるものである.そして，これ らの諸問題は, 対症療法的に対策を施すのみでは, 容易 に解決できるものではないことは良く知られるところで ある.これに対し，自動車に多くを明け渡しすぎた他の 都市交通手段の領域を拡げ，専用空間を確保することに よって, 諸交通問題の原因を根治的に解消しようとする 考え方が，今日いわれるようになってきている.いわ $く$, 大量輸送機関分担率の向上, 歩行者空間の確保等々 である。

そこで，ここでは歩行者空間の確保について考えてみ たい. 歩行者空間は, 自動車出現以前の都市では, 街路 すべてが歩行者空間であったとさえいえるのであり，そ の確保の方法は, 新しい歩行者空間を創造する方法のほ かに, 街路から自動車を締め出すことで歩行者空間を蘇 えらせる方法がある，そして，既成住宅地における場合 のような一般的な場合には, 後者の方法の方が，より容 易で実現性が高いものであると言えよう．前者の方法 は，より理想的あるいは近代的な空間が創造できるとは いえ, その経費と変革の大きさは, あまねく都市全般に 採用することを不可能にしているのである.

とはいえ, この自動車を締出す方法も, 今日のよう に都市生活が自動車に依存することの大きくなっている

\footnotetext{
* 正会員 工修 中部工業大学講師 工学部土木工学科
}

場合，ただちに幹線街路に囲まれる生活道路にすべて採 用することも許されないであろう，それゆえ，既成住区 内の街路（生活道路）は，より歩行者に使われることの 多いものから，選択的に歩行者道化されていかねばなら ない，それでは，歩行者により多く使われる道とは一体 どのようなところに存するのであろうか. また, 歩行者 はどのような道を良い道と考えているのであろうか.さ らにまた，この両者は一致するものなのであろうか。も しこの両者が一致しないとすれば, 前者の良く使われる 道すじを後者の良い道妃改良することが，街路の歩行者 道化の指針として浮かび上ってくるであろう.

本研究では上述のような関係を把握するため, 住民の 街路環境評価の実態を調査するとともに, 歩行者経路を 調查して最短経路との比較において歩行者のより良く使 用する街路を摘出することとした．その上で, 両者の決 定構造を検討してみたい.

本論では, この分析の方法について 2. にやや詳しく 述べ，3.には調查の実施と得られたデータについて略 述している. そして 4. に街路評価と経路選択性向の相 互関係を分析するとともに，そのおのおのを説明するモ デル式を提示する，最後に 5. では，実際の歩行経路が 必らずしも最短経路を採らないことによって生ずる歩行 距離の延長量について分析してみたいと思う.

\section{2. 歩行者の経路選好性向}

\section{（1）分析の方法}

ここでは，歩行者は他の歩行環境に差がないならば， 最短距離の経路を選択するものであるといら仮定を前提 にしている.

そして, 歩行環境に差がある場合は，これを歩行者は 総合的に認識しているものと考え，これを街路評価値 (E) として計量化できるものと考えた.このような環境 
条件の差異もあって, 歩行者は 結果的に起点から終点を結ぶ経 路を選択するのであるが，この 結果, 最短経路上でないにもか かわらず通路として選ばれる街 路は, より選好されている街路 であると考えた。この選好の程 度を表わす指標として経路選好 係数 $(S)$ を考えた.

この街路評価値 $E$ と経路選 好係数 $S$ は, 当該道路のさま ざまな環境条件によって決定さ れるものと考えられる．そこ で，これらを説明するものとし て, 街路区間の道路構造や交通 の状況あるいは，その街路区間 を囲む環境や街路のおかれた都 市計画的位置などを表わす指標 を用意した。これによって， $E$ とSの決定モデルを作成する ことを試みた。

\section{（2）分析の対象とした区域 と地点}

上述の各指標を実際に採録す る対象区域としては, 愛知県犬 山市の駅前地区一帯 (38 ha) を とった．当地区は図一1にみら れるように, 犬山城と名鉄電車 犬山駅に挾まれた区域であっ て, 名古屋市のベッドタウンと 化しつつある犬山市の中では， 古い商住混合の町並を残した落 着いた既成街地である。

この対象区域の中には，一本 だけ県道が走っており,この道 路と犬山城の正門を結ぶ本町通 りに商店街がみられるほかは， 若干の商店, 工業所を混えた住 宅である．歩道は区域境界をなす国道にあるほかは，商 店街のごく一部にあるにすぎない，一般には簡易舗装の 歩車混合街路よりなっており, 最近一方通行, 駐車禁止 を中心としたユニット規制が施行されている．したがっ て，国道々県道以外自動車交通量は多くない（図一1 参照).

この対象区域の中に, 分析の対象とする街路区間を 60 籄所設定した．それを中央地点で表示したものが図一1

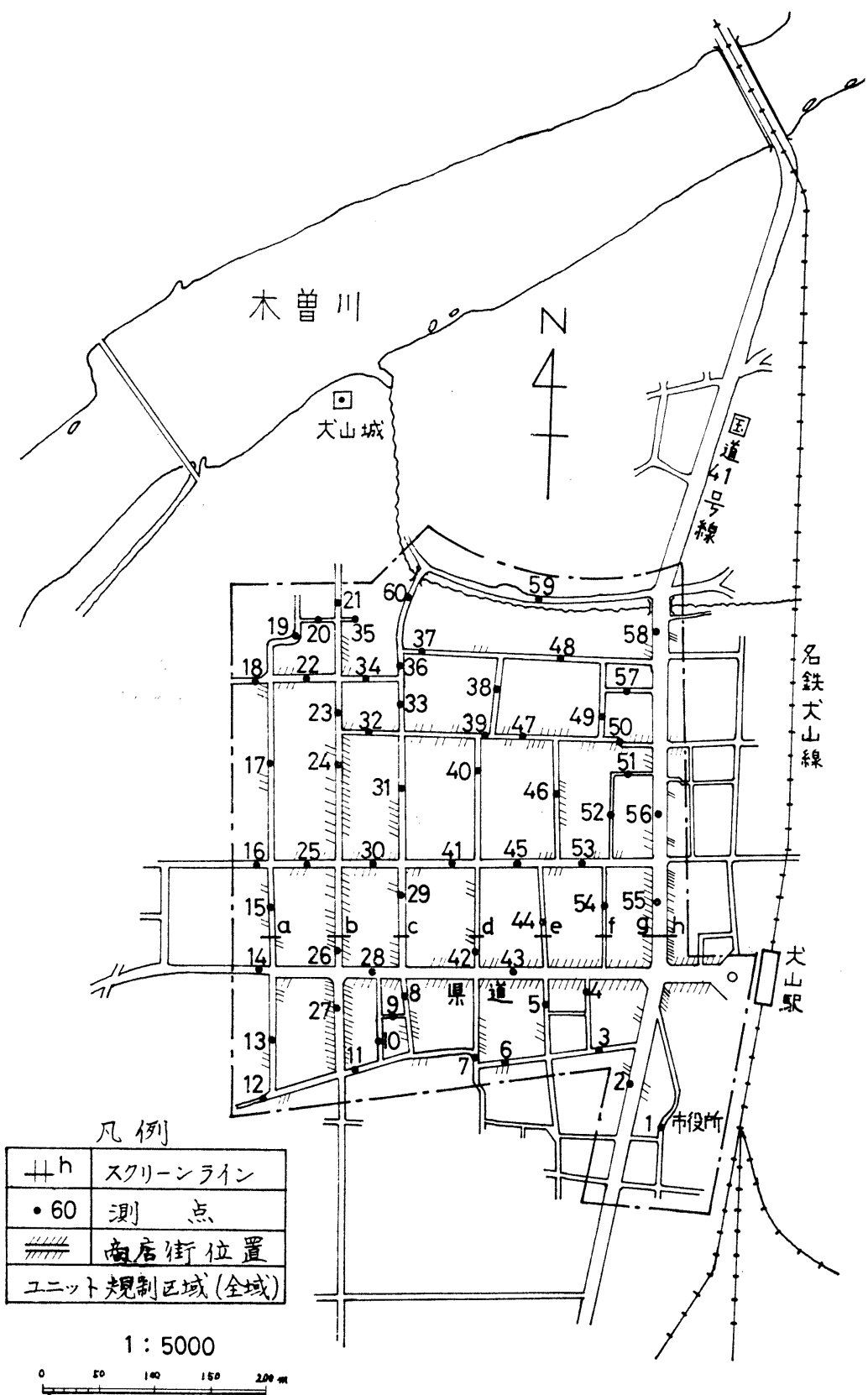

図一1 対象区域地点図

である。

\section{(3) 従来の研究}

この歩行経路の選択性向の研究としては, かつて 1971 年に G. Dietrich ${ }^{1)}$ が，極为てミクロな観点から分析し たものがある.すなわち，矩形の駐車場内を斜断する歩 行者が駐車している車の間隔をどのように選択して経路 を形成していくかを観測したものである。この結果は， 
対角線上をとるか縁辺をいくかが多いのであって，小き ざみな屈曲を伴う経路は選択されないといっている.

また, 今西・越 21 は 1975 年に東京の東横線学芸大学 前駅に集中する歩行者の経路について詳細に分析してい る.ここでは, 歩行経路の迁回は, 最短経路より $50 \mathrm{~m}$ ないしは 10\% 長いものが限度であるといっている。ま た, 経路決定の要因を線形判別関数を用いて分析し, 昼 々夜ではかなり要因の比重が異なることを示している. ここでは商店街の影響が注目される.

さらに, 深海は歩行者流の特徴について, いくつかの 研究を行っているが, 1975 年の報文 ${ }^{3)}$ にれば, 歩行者 の経路選択の動機を各選択点ごとに追跡調査し, 数量化 理論等を用いて分析している. それによれば，やはり経 路選択の最大の要因は商店街に扔いても, 住区内におい ても, 最短経路であり, 続いて商店街では交通規制, 店 舗, 住区内では自然環境であるとしている.

そこで, 本研究では, 上述したように, 最短経路の選 択をまず前提とし，その経路からの逸脱を持たらす要因 を，特に経路選択涼響を与えるものとして分析するこ とにした.こうすることによって，交通計画における歩 行者交通量の街路配分は, まず, 最短経路により, しか る後に本研究の分析結果を用いて修正するという手法が 開発できるものと考えられる.

\section{3. 街路評価値と経路選好係数}

\section{(1) 調査の概要}

以下に述べる各指標を調整するため, 上述の対象区域 に対し次の 3 種の調查を行った。
a) 街路評点員による評点調査
b）歩行者の歩行経路調查
c）街路環境調查

a), b) の調查の意義はすでに述べたとおりである. た, 詳しくは次節に述べる. b) については, ヒアリン グのためのスクリーンラインは県道の北側に入れている (図一1).これは, 県道沿いの商店街および犬山駅に集中 する交通量を主に把えたいためである.なお，歩行者は 参考までに性別，年令層を識別できるように記録してい る. 調查実施日は，a）が 1974 年 11 月 23 日（土, 祝日） の 10 時から 14 時まで, 気候温暖晴天の日であった.ま た，b）は同年11月 1 日（金）で晴天なるも寒い日であ った. 調查時間は，1） $9: 30 \sim 10: 30 ， 2 ） 13: 00 \sim 14$ $: 00,3) 15 ; 30 \sim 17: 00$ の 3 時間帯に分けて行っている.

\section{（2） 街路評価值 $(\boldsymbol{E})$ の測定}

街路評価值の定義法は, 1962 年 $\mathrm{AASHO}^{4)}$ が行った
道路舗装の走行性を評価するサービス指数の定義方法と 同様のものである.

まず，道路評点員を数十名用意する，今回性市民各層 から, 対象地区を良く知っている 22 名を選択した.こ れらの評点員を引率して, 評価をしたい街路区間に赴 き, 10 点満点でその道路環境に評点をつけさせる.こ の場合の評点基準については,

a）歩いて大変楽しく，ゆったりと歩け，ここなら子 供ひとりで歩いても安全だと思うならば …………10 点

b）舗装状況等の諸条件を考え，一応安全であるが， 決して良い道路であるとはいえないと思らならば ‥5 点 c）この道路は迂回して行った方が良いほど好きでな く危険で不快であると思うなら………………….... 点 とだけ各評点員に説明してあり，他には全く予断を与え るような示唆はしていない。

ここで評点採点を 10 段階としたため, 老人と主婦の 一部に採点の単純化 (ほとんど $0,5,10$ 点のいずれかと いうようなもの) が見受けられたが, 全体としては正常 な正規型の分布をしている. また, 各員の平均点の分布 も 2 人を除いて 4.6 6.0 の間に入っており分散は小さ い.また階層による平均点のかたよりも見られない.こ のた为, 各地点の評価値は単純に 22 人の評点を平均す ることにした.

60 箇所の地点の街路評価值 $(E)$ の分布は 図一2 のよ うになり, 平均值 5.2 を中心正規型の分布をしてい る.しかし, 各地点の評点員ごとの評点のばらつきは, かなり存在している. それゆえ, 街路評価については, この平均值である評価值以外に標準偏差についても計算 してみた. 表一1 には, 各地点の街路評価値と評点の標 準偏差を示した. これより判るように, 標準偏差は各地 点とも良く似た值を示している $(0.9 \sim 2.7)$. 一方, 平 均值はかなりの差がある。

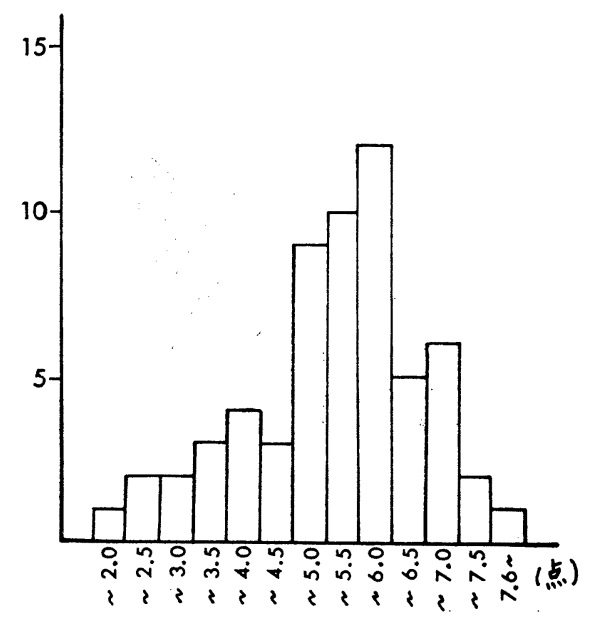

図一2 街路評価值の分布 
表一1 街路評価值と経路選好係数

\begin{tabular}{|c|c|c|c|c|c|c|c|c|c|c|c|c|c|}
\hline \multirow{2}{*}{$\begin{array}{l}\text { 地点 } \\
\text { 番 号 }\end{array}$} & \multirow{2}{*}{$\begin{array}{c}E \\
\text { 評 価 值 }\end{array}$} & \multirow{2}{*}{$\begin{array}{c}E の \\
\text { 標準偏差 }\end{array}$} & \multirow{2}{*}{$\begin{array}{c}E の \\
\text { 変動係数 }\end{array}$} & \multicolumn{3}{|c|}{ 選 好 係 数 $S$} & \multirow{2}{*}{$\begin{array}{l}\text { 地点 } \\
\text { 番 号 }\end{array}$} & \multirow{2}{*}{$\begin{array}{c}E \\
\text { 評 価 值 }\end{array}$} & \multirow{2}{*}{$\begin{array}{c}E の \\
\text { 標準偏差 }\end{array}$} & \multirow{2}{*}{$\begin{array}{c}E の \\
\text { 変動係数 }\end{array}$} & \multicolumn{3}{|c|}{ 選 好 係 数 $S$} \\
\hline & & & & 駅 向き & 逆向き & 平 & & & & & 駅 向き & 逆 向き & 平 \\
\hline 1 & 5.00 & 1.02 & 0.21 & 0.61 & 0.00 & 0.41 & 31 & 6.10 & 1.36 & 0.22 & 0.04 & 0.17 & 0.10 \\
\hline 2 & 3.70 & 2.74 & 0.74 & 0.45 & 0.48 & 0.46 & 32 & 5.80 & 1.26 & 0.22 & -0.47 & -0.65 & -0.55 \\
\hline 3 & 6.80 & 1.41 & 0.21 & 0.30 & -0.18 & 0.08 & 33 & 5.00 & 1.30 & 0.26 & 0.21 & 0.26 & 0.24 \\
\hline 4 & 5.70 & 2.10 & 0.37 & -0.26 & -0.89 & -0.52 & 34 & 5.70 & 1.09 & 0.19 & -2.00 & 1.11 & 1.53 \\
\hline 5 & 6.30 & 1.42 & 0.23 & -0.09 & -0.39 & -0.23 & 35 & 4.80 & 2.48 & 0.52 & - & - & - \\
\hline 6 & 5.80 & 1.28 & 0.22 & 0.65 & -0.44 & 0.00 & 36 & 5.50 & 1.23 & 0.22 & 0.07 & 0.21 & 0.15 \\
\hline 7 & 4.90 & 1.39 & 0.28 & 0.43 & -0.28 & -0.10 & 37 & 5.90 & 1.33 & 0.23 & -2.00 & -2.00 & -2.00 \\
\hline 8 & 5.50 & 1.23 & 0.22 & -0.02 & -0.10 & -0.06 & 38 & 5.50 & 1.27 & 0.23 & 0.30 & 0.29 & 0.19 \\
\hline 9 & 5.60 & 1.95 & 0.35 & -1.07 & -2.00 & -1.55 & 39 & 5.10 & 0.88 & 0.17 & -0.44 & 0.13 & -0.14 \\
\hline 10 & 5.80 & 2.17 & 0.37 & -0.56 & -2.00 & -0.93 & 40 & 6.00 & 1.13 & 0.19 & -0.34 & -0.46 & -0.40 \\
\hline 11 & 4.90 & 1.12 & 0.23 & -0.36 & -0.58 & -0.48 & 41 & 5.70 & 1.21 & 0.21 & -0.28 & -0.36 & -0.31 \\
\hline 12 & 6.80 & 1.38 & 0.20 & - & - & - & 42 & 6.10 & 1.01 & 0.17 & 0.03 & 0.26 & 0.15 \\
\hline 13 & 6.80 & 1.23 & 0.18 & 0.44 & 0.30 & 0.38 & 43 & 4.00 & 1.60 & 0.40 & 1.13 & 0.44 & 0.67 \\
\hline 14 & 1.80 & 1.82 & 1.01 & - & - & - & 44 & 7.30 & 1.21 & 0.17 & -0.27 & -0.36 & -0.31 \\
\hline 15 & 5.30 & 1.22 & 0.23 & -0.20 & 0.62 & 0.23 & 45 & 6.40 & 1.22 & 0.19 & -0.28 & -0.46 & -0.36 \\
\hline 16 & 4.40 & 1.40 & 0.32 & - & - & - & 46 & 5.50 & 1.23 & 0.22 & 0.15 & 0.47 & 0.33 \\
\hline 17 & 6.70 & 1.46 & 0.22 & -0.13 & 0.55 & 0.25 & 47 & 5.70 & 0.96 & 0.17 & 0.06 & -0.31 & -0.14 \\
\hline 18 & 6.20 & 1.99 & 0.32 & - & - & - & 48 & 5.90 & 1.20 & 0.20 & 0.72 & -2.00 & 0.78 \\
\hline 19 & 7.00 & 2.07 & 0.30 & -0.81 & 0.50 & -0.91 & 49 & 5.20 & 1.03 & 0.20 & -0.98 & 0.25 & -0.49 \\
\hline 20 & 6.60 & 1.47 & 0.22 & 0.48 & -0.88 & -0.33 & 50 & 4.00 & 1.73 & 0.43 & -0.23 & -0.30 & -0.25 \\
\hline 21 & 4.60 & 1.19 & 0.26 & - & - & - & 51 & 2.60 & 1.92 & 0.74 & 0.46 & 0.78 & -0.60 \\
\hline 22 & 5.30 & 1.48 & 0.28 & 0.06 & 0.26 & 0.12 & 52 & 3.40 & 1.77 & 0.52 & - & - & - \\
\hline 23 & 2.40 & 1.61 & 0.67 & -0.22 & 0.07 & -0.08 & 53 & 5.10 & 1.18 & 0.23 & 0.99 & 0.27 & 0.22 \\
\hline 24 & 3.10 & 1.67 & 0.54 & -0.11 & 0.83 & 0.26 & 54 & 5.40 & 1.22 & 0.23 & 0.00 & 0.43 & 0.19 \\
\hline 25 & 3.60 & 1.67 & 0.46 & 0.25 & 0.17 & 0.22 & 55 & 2.80 & 2.02 & 0.72 & 0.31 & 0.32 & 0.31 \\
\hline 26 & 2.80 & 1.62 & 0.58 & 0.05 & 0.77 & 0.43 & 56 & 3.10 & 2.03 & 0.65 & 0.14 & 0.25 & 0.19 \\
\hline 27 & 7.20 & 1.59 & 0.22 & 0.51 & 0.01 & 0.25 & 57 & 4.30 & 1.10 & 0.26 & -2.00 & 0.00 & -0.40 \\
\hline 28 & 4.20 & 1.64 & 0.39 & 0.84 & 0.14 & 0.36 & 58 & 4.70 & 2.14 & 0.45 & 0.06 & 0.37 & 0.20 \\
\hline 29 & 5.00 & 1.48 & 0.30 & -0.08 & 0.51 & 0.15 & 59 & 8.60 & 1.07 & 0.12 & 0.43 & 0.60 & 0.48 \\
\hline 30 & 4.90 & 1.49 & 0.30 & -0.20 & 0.15 & -0.08 & 60 & 6.00 & 1.66 & 0.28 & 0.30 & 0.06 & 0.15 \\
\hline
\end{tabular}

\section{（3）経路選好係数の計算}

経路選好倸数を計算するために，歩行経路の調查を行 った．調查区域内に設定したスクリーンラインを通過す る歩行者に，起点および終点と歩行経路をヒアリング し，地図上に記録したものである。これを $\mathrm{OD}$ 表と各街 路区間ごとの断面交通量の両データとして整理する.こ の場合, 調査区域外に起終点のあるものは同区域一の流 出入点をもって起終点としている．なお，この調査で得 られたサンプルは 842 トリップであり，ノード数 58 の $\mathrm{OD}$ 表に展開された場合，トリップの配分のみられる OD ペアは 352 であった．この中では駅前や商店街のノ 一ドを起終点とするものが大きな值を示している.

次に, 調查区域の全街路網㧍よびその周辺部の一部街 路をとり入れたネットワークを形成し，これに最短経路 に従って，上述の OD 交通量を配分する，いま，この 配分によっ得られた各リンクの断面交通量を $Q_{\mathrm{opt}}$ とす る. 先述の当該街路区間に発生している断面交通量実現 值を $Q_{r}$ とすると, 経路選好係数 $S$ は次式で定義され る.

$$
S=\log \frac{Q_{r}}{Q_{\mathrm{opt}}}
$$

この $S$ は，当該街路区間が，最短経路上に現われる

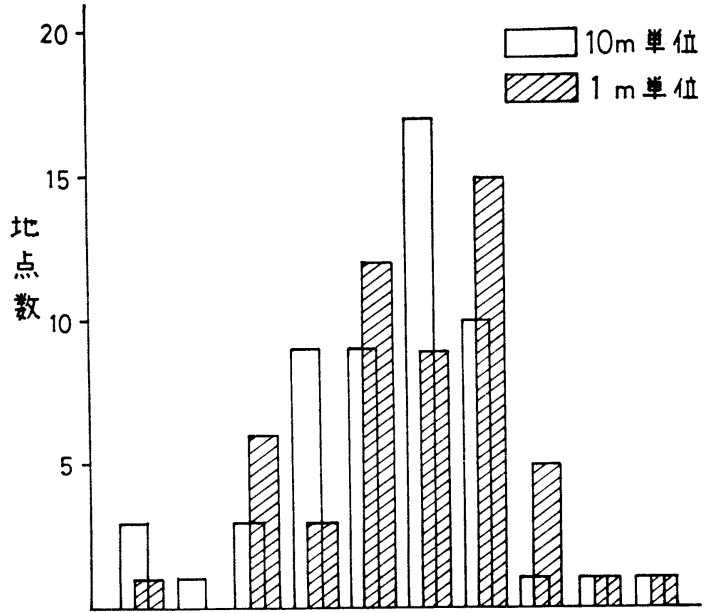

$--1.01-1.00-0.75-0.50 \sim-0.25-0.00-0.25-0.50-0.75-1.00$

\section{図一3 経路選好係数分布図}

ことが少ないにもかかわらず良く利用されているとき正 となり，逆の場合に負となる．また対数をとることによ り，図一3 にみるように $S$ の分布は，0.0を中心とし たより左右対称に近い分布型を示すようになる。

式 (1) による $S$ の計算値は, 最短経路測定の精度に よって若干異なった值を示すようになる.図一 3 は, $1 \mathrm{~m}$ 
の精度で測った場合と $10 \mathrm{~m}$ の精度の場合の比較である。 後者の場合は等距離経路が多く現われ，交通量を複数経 路に等分配分をする必要が生ずる.ここでは，後者の方 が分布型が整っているし，歩行者の 距離認識の 精度も $10 \mathrm{~m}$ よりも厳密ではないと思われるので, 後者の $10 \mathrm{~m}$ 精度の経路探索によるものを経路選好係数 $S$ として採 用することにした．

また，この $S$ 洛各地点ごとに両方向ずつ計算される． 上下両方向の $S$ 值の間には大きな差のあるものもある. そこで, ここでは犬山駅に向う方向と逆方向という基準 で整理し, 両方向の $S$ 值 (以後「駅向き $S 」$ と「逆向 き $S\lrcorner$ という) と合計の $S$ 值（以後「平均 $S\lrcorner$ という） を用意し，しばらくは並行して分析しつつ，その特性を みていくことにしたい，表一1にはこの值も併載した。

なお, 評価值 $E$ を計算した 60 地点のうち, 7 地点 は対象区域の周辺にあり，スクリーンラインとの位置関 係から該当の歩行者交通を捕捉できず，この経路選好係 数は算出ができない.したがって, デー夕数は 53 であ る.

\section{（4）街路環境指標}

歩行者が道路を通行するときの環境条件は，道路構造 にかかわるものと, 通行時に歩行者が感覚するいわゆる 通行環境および交通量等の状態に 分類することができ る.

\section{a) 街路の道路条件}

道路構造については, 道路幅員, 歩道形態, 舗装状 況, 側溝の構造, 縦断勾配, 道路屈曲角について調查し た. このうち，一部の項目については各地点間に有意な 差が認められなかったものもあり，分析用のデータから は除外した。たとえば舗装はほとんどアスファルトの簢 易舗装であった。また，縦断勾配は $5 \%$ を越えるものは

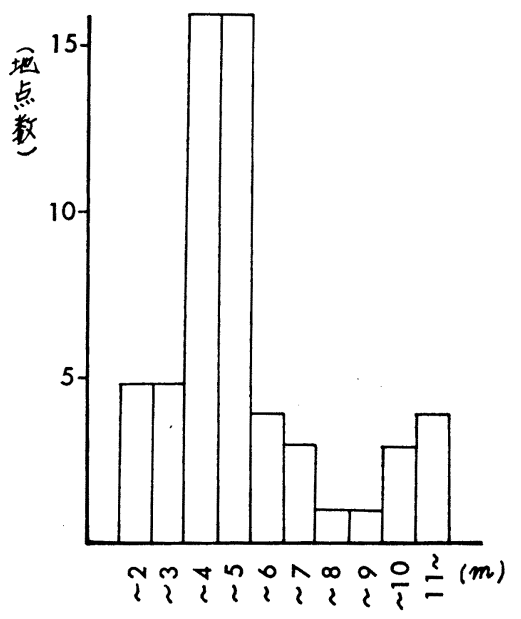

四一４総幅員の分布
表一2 歩道形態と側溝構造の分布

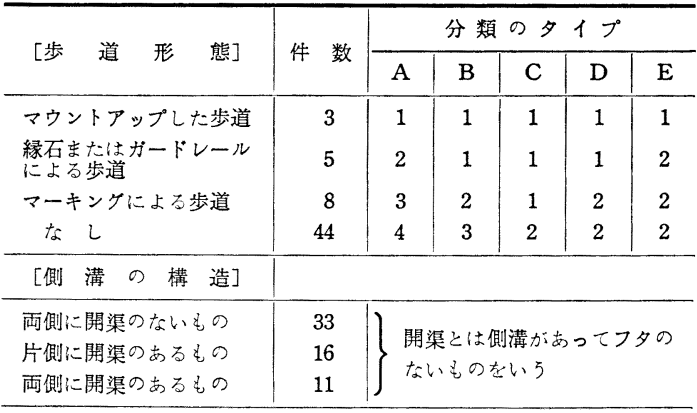

見られない。

こうして, 道路構造に関する指標は道路幅員w（単位 $\mathrm{m})$, 歩道の形態, 側溝の構造の 3 項目に限ることにし た．道路幅員は歩道を含む総幅員で $3 \mathrm{~m} \sim 5 \mathrm{~m}$ のものが 多くなっている (図一4). また, 歩道の形態および側溝 の構造についての分類と調查結果は表一2 に示した. い ずれにしても，歩道幅員 $2 \mathrm{~m}$ 以上のものはみられなか った.

\section{b）街路の歩行環境}

歩行者が何を見，何を感じながら歩くかは大変わかり がたいのであるが，ここでは歩行の環境を表わす指標と して, 道路の閉塞感を示寸天空率 $h$ (単位 \%), 環境樹 の量を表わす緑率 $g$, 道路の都市施設環境を示す商店数 $m$ の 3 項目を採ることにした. このほかにも，沿道施 設の高さと軒さがりによって閉塞感を表わすことを考え たが，結局天空率の方が使いやすかった．また，自然環 境としては塀の種類や沿道の土地利用をも調べたが，そ の代表指標として視野に入る緑の量をとることにした。

天空率 $h$ とは, 各地点において道路中心線上の一定 の高さから同一カメラ (OLIMPAS OM 1 F 3.5, $f=$ $28 \mathrm{~mm}$ ) で道路中心線にそって通常の歩行者の視線方向 と考えられる鉛直角で（平坦部では中心線に平行）撮影 した写真の画面から，天空の面積比率を計測したもので ある. 今回の区域では，大変狭い裏路などもあるので， 図一5 に示すように 10\% 以下の天空率を示すものもあ

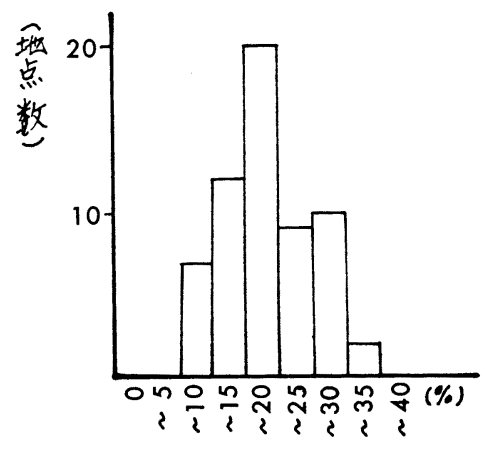

図一5天空率の分布 


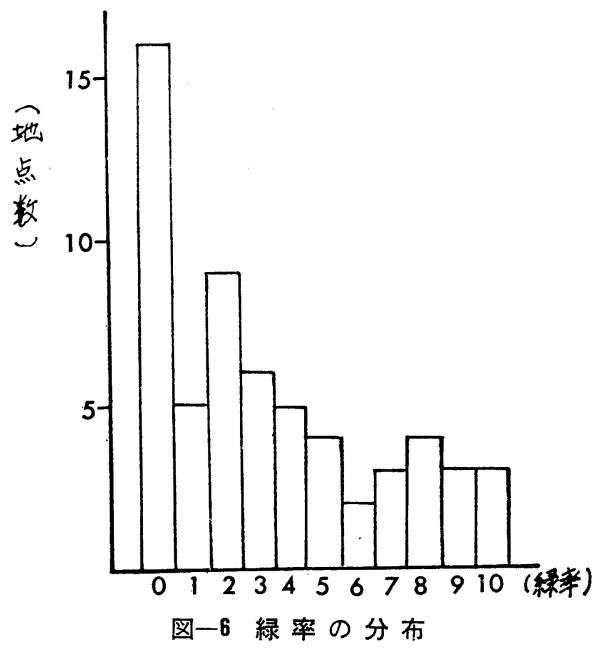

るが，一般に 10〜30\% の值を示している.

緑率 $g$ は同じ写真の画面から樹木, 鉢植など緑の占め る面積を計り, 今回のサンプルのうち最も大きいものを 10 点として指数化したものである. したがって一般的 なデータではない. 分布は図一6 に示したが，1/4 が全 く緑がなく 0 点である.

商店数 $m$ (単位, 軒 $/ 100 \mathrm{~m}$ ) は, 分析地点の前後 50 $\mathrm{m}$ ずつの街路区間の両側に面している店舗, 事業所の 軒数を数えたものである. 商店数は, 道路沿道の土地利 用が経済活動の上で高度化していることの指標であると 考えられるので, 事業所には商店数という用語にふさわ しくないものもあるが,ここでは，これに含めることに している. なお, 街路の屈曲により $100 \mathrm{~m}$ の延長が確 保できない区間では，見通せる限りとした。したがっ て, 厳密な商店密度にはなっていない. しかし, 歩行者 の商店街の認識は，実際に店舗が見えるか否かにあろ う. したがって, ここではあえて商店数そのものを指標 とすることにした. 実際, 分析の結果滳店密度よりも この方が説明的であった. 分布状況は 3 店以上は 19 箇 所, 1 つも店のないのが 21 箇所となっており, 10 店以 上は 4 箇所である.

c）道路交通量の条件

対象区域の交通量調查は 1974 年 11 月 1 日（金）に, 1) $8: 00 \sim 9: 00$, 2) $11: 00 \sim 12: 00$, 3) $14: 30 \sim$ $15: 30$ の 3 時間にわたって実施している. この 3 時間 を合計した自動車交通量を算出した（単位・台 $/ 3 \mathrm{hr}$ ). 国道では 3500 台 $/ 3 \mathrm{hr}$ 以上の值が出ているが, 150 台/ $3 \mathrm{hr}$ 未満の地点が半数近くある. なお, この交通量を計 測できた地点は, 上述の 60 地点中 45 地点のみである.

次に, 1975 年 11 月 14 日 (金)に駐車実態の調查を 行った. この地区は全面的に駐車禁止となっているので あるが, 実際には 31 地点 (8 地点観測できず) におい て駐車がみられた。この観測は 1 日に 4 回, 全道路を巡
回し, 各地点から見通せる駐車台数 (単位・台) を計数 したものである.ここでは, 先の商店数と同じ理由によ り，単純にその台数を指標としている.

以上の 8 項目の街路環境の条件を表わす指標を用意し た.

\section{4. 街路評価モデルと経路選択モデル}

\section{（1） $E$ ट $S$ の関係}

さて, 上述の街路評価值 $E$ と経路選好係数 $S$ は 53 の 同一地点において算出されているので, いまこの両者の 相関を調べてみる. その結果は相関係数 $r=-0.09$ とな り，両者の間にはほとんど何らの相関性を見出すことも できない. すなわち， $E$ と $S$ は全く異なった決定機構 を持っているようである.このことは， $E$ と $S$ おのお のの街路環境指標との相関のあり方にも現われている.

表一3 は街路環境指標のうち連続量で表わされる 6 指 標と $E$ および $S$ の単相関分析結果を示したものであ る. また, 歩道形態と側溝の構造については表一2に示

表一3 単相関分析結果表（相関係数）

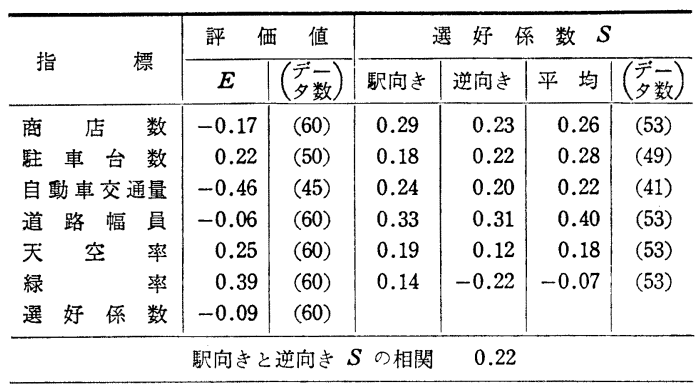

表-4 分散分析 $\boldsymbol{F}$ 值表

\begin{tabular}{|c|c|c|c|c|c|c|c|}
\hline \multirow{2}{*}{ 分類名 } & \multirow[b]{2}{*}{ 数 } & \multirow{2}{*}{$\begin{array}{c}\text { 評価値 } \\
E\end{array}$} & \multicolumn{3}{|c|}{ 選 好 保 数 $S$} & \multicolumn{2}{|c|}{$\alpha=0.01 の F$ 值 } \\
\hline & & & 駅向き & 逆向き & 平 均 & \multicolumn{2}{|c|}{ テ -夕数 } \\
\hline \multicolumn{2}{|c|}{ サンプル数 } & 60 & 53 & 53 & 53 & 60 & 53 \\
\hline 側 溝 構 造 & 3 & 1.86 & 1.03 & $4.28^{* *}$ & 3.17 & 5.00 & 5.10 \\
\hline 首形態 A & 4 & $5.42^{*}$ & 0.77 & $4.31^{*}$ & $4.66^{*}$ & 4.20 & 4.25 \\
\hline 同 B & 3 & 3.00 & 0.52 & $6.52^{*}$ & $6.90^{*}$ & 5.00 & 5.10 \\
\hline C & 2 & & 0.8 & $13.30^{*}$ & $13.28^{*}$ & 7.1 & 7.20 \\
\hline D & 2 & & 0. & & 7.9 & 7. & 7.20 \\
\hline 同 & 2 & 0.00 & 1.13 & 0.90 & 1.19 & 7.10 & 7.20 \\
\hline
\end{tabular}

* $\alpha=0.01$ で有意な $F$ 值 (** は $\alpha=0.025)$

表一5 経路選好係数の層別平均值

\begin{tabular}{|c|c|c|c|c|c|}
\hline- & 頻タイプ & & & & \\
\hline 層 & デー夕数 & 平均 值 & $\begin{array}{c}\text { 変動係数 } \\
(\%)\end{array}$ & 平均值 & $\begin{array}{c}\text { 変動保数 } \\
(\%)\end{array}$ \\
\hline $\begin{array}{l}\text { マウントアア } \\
\text { ップ+緣石 }\end{array}$ & 8 & 0.442 & 104 & 0.347 & 107 \\
\hline マーキンク & 8 & 0.252 & 100 & & \\
\hline な & 37 & -0.179 & 292 & -0.179 & 292 \\
\hline
\end{tabular}


したカテゴリー定義（歩道形態の分類は 5 つのタイプ 考えた）に従って一元配置の分散分析を行った結果を表 -4 に示している. 街路環境指標はすべての観測点に用 意できたわけではないので, 表にみるようにデー夕数は 若干の変動があるが，いずれにしても有意な相関関係を 判定するには, 単相関分析においては相関係数が $r=$ 0.25 以上になることが必要であろう。また，分散分析 において要求される有意な層間格差判定のための $F$ 值 は表一4に併記してある.

これより, 評価値 $E$ は自動車交通量 $q$ 亿負の, 緑率 $g$ に正の相関がみられるのに対し, 選好係数 $S$ は道路 幅員wとの間に正の相関がみられるのみである.さら に分散分析の結果からは, 歩道形態が $E, S$ ともに影響 を与えていることがわかるのであるが，Eでは歩道形態 を細かく分類した場合に影響が明確になるのに対し， $S$ では歩道の有無のみが影響するように見受けられる。た だし，マーキングや縁石といった中途半端な歩道では， $E$ の值歩道のない場合よりもむしろ低い值を示してい ることが注目される．Sの場合については，その分析結 果を表一5に示した。

このように, 評価値 $E$ と選好保数 $S$ は, 相互の間に 相関はなく，おの扔のを決定する要因も大きく異なって いることがわかる．そこで以下には $E$ および $S$ の決定 モデルを全く独立に求めてみることにしたい.

なお, 上述の議論では経路選好係数に平均 $S$ をとっ て考察しているが， $S$ の反応は駅向き $S$ と逆向き $S$ と で, かなりパターンの相違があることが 表一3，4 から 読みとれる.すなわち, 商店数や自動車交通量, 道路幅 員など街路の繁華性を表わす指標に対しては，駅向き $S$ の方が弱いながらも正の相関を示そうとするのに対し， 歩道形態汶しては逆向き $S$ が強い関連性を示し, 駅 向き $S$ ではそれが見られないのである.これは，いま 駅向き $S$ が主として目的地に向から途上のトリップに よって算出され，逆向き $S$ が帰宅トリップによって算 出されていると考えうるとすれば, 歩行者は往路海繁華 で機会の多い経路を, 帰路は安全な経路を選択するとい うことができる.しかし，今回の調査ではトリップの目 的を調べていないので，上述のトリップの方向と目的の 対応は，あくまで推測の域を出ない。したがって, 以下 の議論では選好係数 $S$ はすべて平均 $S$ を用いていくも のとする.

\section{(2) 街路評価モデル}

単相関分析の結果より評価値 $E$ に関しては有意な相 関を示卞街路環境指標が複数見られるので，ここではこ れらの指標を説明変数とするもっとも説明力のある重回 帰式を変数減少法により求めることにする. 説明変数に
は，その值が 0 となりうるものが存在し，この場合も $E$ 值は 0 でないことがいえるので, 式の形は一次結合と仮 定している.

重回帰分析の結果, 自由度調整済みの決定係数が最高 (0.59) になるのは次の式であった.

$$
\begin{aligned}
E= & 3.157-0.086 m-0.00151 q \\
& +0.392 w+0.0400 h+0.114 g
\end{aligned}
$$

ここで, $m$ は商店数 (軒 $/ 100 \mathrm{~m}), q$ は自動車交通量 (台 $/ 3 \mathrm{hr}$ ), $w$ は道路幅員 $(\mathrm{m}), h$ は天空率 (\%), $g$ は 緑率 (点) を表わ寸. 重相関係数は $r=0.80$ であり, か なりの変動が説明できたと見て良いであろら，F值は， $F=11.18$ であり, この場合, 有意水準 $5 \%$ の $F$ 值は 2.53 であるので, 回帰係数全体としての有意性は確認 できる.

これより，式 (2) を街路評価モデルと考えることがで きる. 評価值は商店数と自動車交通量の多いところほど 低く, 道路幅員が広く, 天空が広がり, 緑の多いところ ほど高くなることがわかる，なお，式 (2) の回帰係数よ 门標準回帰係数を計算してみると, 自動車交通量の影響 が最も大きく, ついで道路幅員, 商店数となってお敌り, 緑率, 天空率は, 他と比べて影響力は少ない。

\section{（3）経路選択モデル}

経路選好係数 $S$ を説明するモデル式は 3 つのものを 作成した. すなおち, (1) 上述の街路評価モデルのよう な連続量の環境指標を説明変数とした 重回帰式, (2) こ れに歩道形態をダミー変数として加えた重回帰式，およ び (3) 数量化理論 I類を用いたモデルの 3 種である.

単純な重回帰式としては説明変数を 3 つ用いた場合に 最も合理的なものが得られた。

$$
S=-0.098+0.021 m+0.00009 q
$$

しかし, この式 (3) は重相関係数 $r=0.53, F$ 值は 6.58 であって有意水準 $5 \%$ で回帰係数の有意性は確認できる ものの，必ずしも十分な説明力を持っているとはいえな いであろう。

歩道形態をダミー変数として式 (3) に加えるにあたっ ては, 歩道形態の分類タイプ Bと Cの 2 ケースについて 試みてみた (表一2 参照).

分析の結果, 決定倸数は 2 分類の場合が $0.324,3$ 分 類の場合が 0.344 であった. 式 (3) の決定係数は 0.285 であるので 4 6\% の説明力の向上がみられる. しかし， 両方ともダミ一変数により増加した回帰変動量の, 残差 変動に対する分散比 $F$ は, 1.92 および 1.48 にしかな らず，ダミ一変数を用いて求めた定数項の層間差は有意 であるとはいえない.いま, 求められた式を示して抢け ば, 2 分類の場合, 次のようなものである.

$$
S=C+0.015 m+0.00004 q
$$




\section{表一6 数量化理論分析結果}

\begin{tabular}{|c|c|c|c|c|}
\hline アイテム & カテゴリー & サンプル数 & $\begin{array}{l}\text { カテコリリ } \\
\text { ス }\end{array}$ & (偏相関係数) \\
\hline 歩道形態 & $\begin{array}{l}\text { 歩道なし } \\
\text { マーキンタ } \\
\text { 歩道あり }\end{array}$ & $\begin{array}{r}35 \\
7 \\
7\end{array}$ & $\begin{array}{r}-0.022 \\
0.166 \\
0.218\end{array}$ & $\begin{array}{c}0.241 \\
(0.238)\end{array}$ \\
\hline 駐車の有無 & $\begin{array}{l}\text { 有 } \\
\text { 無 }\end{array}$ & $\begin{array}{l}31 \\
18\end{array}$ & $\begin{array}{c}0.0 \\
-0.043\end{array}$ & $\begin{array}{c}0.043 \\
(0.056)\end{array}$ \\
\hline 商店の有無 & $\begin{array}{c}\text { 無 } \\
\text { やあり } \\
\text { 商 店 街 }\end{array}$ & $\begin{array}{r}28 \\
16 \\
5\end{array}$ & $\begin{array}{l}0.0 \\
0.121 \\
0.254\end{array}$ & $\begin{array}{c}0.254 \\
(0.202)\end{array}$ \\
\hline 道路種別 & $\begin{array}{l}\text { 国県道 } \\
\text { 一般市道 } \\
\text { 裏 道 }\end{array}$ & $\begin{array}{r}5 \\
37 \\
7\end{array}$ & $\begin{array}{c}0.0 \\
-0.064 \\
-0.466\end{array}$ & $\begin{array}{c}0.466 \\
(0.366)\end{array}$ \\
\hline
\end{tabular}

\section{表一7 経路選択モデルの推計残差比較}

\begin{tabular}{|c|c|c|c|}
\hline モデル & $\begin{array}{c}\text { 式(3) } \\
\text { 回帰モデル }\end{array}$ & ダミー変数モデル & 数量化モデル \\
\hline 観 測值 の平均 & \multicolumn{2}{|c|}{0.0257} & $-0.0261^{*}$ \\
\hline 推計值 の平均 & 0.0213 & 0.0136 & -0.0261 \\
\hline 観 測 值の 標準偏差 & \multicolumn{2}{|c|}{0.5055} & $0.4038^{*}$ \\
\hline 推計值の 標準偏差 & 0.1618 & 0.1618 & 0.2631 \\
\hline 推計残差の平均 & 0.0045 & 0.0121 & 0.0000 \\
\hline 推計残差の標準偏差 & 0.4816 & 0.4653 & 0.3064 \\
\hline$F^{*} \quad-\quad$ 夕 数 & \multicolumn{2}{|c|}{42} & $49^{*}$ \\
\hline$\chi^{2} \quad$ 值 & 13.569 & 13.365 & 14.635 \\
\hline
\end{tabular}

*アイテムの関係で使用したデー夕数が異なっている。

$$
C\left\{\begin{array}{l}
=0.058 \text { (歩道のある場合) } \\
=-0.120 \text { (歩道のない場合) }
\end{array}\right.
$$

数量化理論のI類を用いたモデルについては,さまざ まに説明アイテムを組合せてみた結果，表一6のような モデル式を得た．ここで使用されたアイテムは歩道形態 ( 3 カテゴリー), 駐車の有無 ( 2 カテゴリー), 商店の 有無 ( 3 カテゴリー), 道路の種類 ( 3 カテゴリー) で ある. 商店の有無は, 商店街と言うほどでないものをや やありとして分類している．また，道路の種類はほぼ自 動車交通量の多寡を表わしているとみることができるの であって，裹道とは物理的に自動車の進入できないよう なものである.

分析の結果は表一6にみるように，すべてに合理的な カテゴリースコアの分布をみており, レンジは道路の種 類が最も大きく, 駐車の有無はほとんど意味のあるレン ジを持たない，すなわち，国・県道ほど，歩道のあるほ ど, 商店のあるほど $S$ 值は高くなることを示している. アイテム相互の相関性は, 商店の有無と歩道形態がやや 高くなっているが，一応たがいに独立と見て良いである 5. 重相関係数は $r=0.651$ であった. 分析に用いられ たデータ数は 49 である. この相関係数をただちに, 重 回帰分析の相関係数に比較するわけにはいかないが，そ れにしても後者よりかなり良い相関係数が得られたもの と見て良いであろう。

この 3 つの経路選択モデルのどれが良いモデルである
かについては，直載に判定することは難しいのである が,ここではこれらのモデルによって推計した值と観測 值との差について検討することによって，モデルそれぞ れの特色を検討しておくことにする.

推計モデルの有效性を計る一つの目安として, 推計值 の平均值と標準偏差が観測值のそれと近い值が得られて いるかどうかを見る方法がある．表一7にはこれらの計 算結果が表示してある.これによると, 数量化モデルは 平均值が良く一致しているが, 他のモデルでは推計值の 平均がやや小さくなっている.このことは, 回帰モデル がやや過小推計をする傾向があることを示している。こ れは，観測值から推計值を引いた推計残差の平均が正の 值をとっていることからもわかる，そして，その偏差は ダミー変数を用いたモデルが最も大きい, 一方, 標準偏 差はいずれのモデルによる推計值も観測より小さくなっ ており，これらのモデルが十分に選好係数 $S$ の変動を 説明しきっていないことを示している.この点でも数量 化モデルが最も良い推計值を与えている.

いま一つの比較検討の方法として, 推計誤差の総量を 示す指標として次式に示すような $\chi^{2}$ 值を算出寸ること もできる。

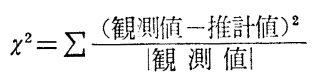

この計算結果も表一7に示してあるが，これも推計演算 をしたデータ件数を考えると数量化モデルが最も誤差量 の少ないことを示している．このように，3つの経路選 択モデルの中では, 数量化モデルが最も良いモデルであ るといえる。

\section{（4）歩行者の経路選択と街路評価}

以上の経路選好係数 $S$ と街路評価值 $E$ の分析より得 られた結果をまとめてみると次のようになる。

経路選択モデルとして最も良好なモデルといえるのは 表一6 に示寸数量化理論によるモデルである.これによ ると，歩行者は最短経路からはずれて歩行経路を選択す る場合, 国道・県道といった広い道路, 歩道がはっきり 整備されている道路, 商店街のある道路といった, 繁華 な経路を多く選択することがわかった。 そして, 道の閉 塞感や環境樹の有無といったものは, 経路の決定に影響 を与えていない.

これに対し, 街路評価の実態は実際の経路選択とは全 く独立している.式 (2)によれば, 自動車交通量の少な いところほど，また道路幅員の広いところほど，そして 寄与の程度は低いが, 商店の少ないほど, 天空率が大き いほど，環境の緑が多いほど，人々は良い街路であると 判断しているのである.

もちろん今回の調査が, 散歩などのトリップの少ない 
駅前地区といった地区のデータに偏していることの限界 もあろうが,ここに得られた歩行経路の決定に, 街路の 快適さがあまり影響しないという結果は重要である.し かも人々は快適さのある道路を良い道路であるとは評価 しているのである.これより, 歩行者空間の整備は, 商 店街や基幹的道路において, 歩道を整備し, 自動車交通 量を減じ, 開放感のある緑の多い環境を創出する方向に 向けられるべきであるといら結論が導かれるであろら.

以上に両モデルから読みとられる結論をまとめたので あるが, 経路選択モデルにおいてはいまだ推計残差の無 視し得ない若干の地点が見られる.これらの地点の特徵 を吟味しておくことは今後の研究発展のために参考にな ろう。また, 最短経路をはずれて迂回経路を採る歩行者 の, その迁回距離の限度はどのようなものであ万うか. 次章では, これらの点について若干の考察をしておくこ ととしたい。

\section{5. 街路の個性と迂回距離}

\section{(1) 街路の個性}

本研究で経路選択モデルの説明変数に用いた街路環境 指標は, いずれも大部分の観測点に共通して観測しうる 特性を用いている.しかし，街路の環境条件にはある地 点にだけ存在する他との比較を許さない固有の条件が存 在する.これらの条件は今回のモデル解析では除外され ているのであるが，完成したモデルを用いて経路選好係 数の計算值を求め, それを当該の観測值と比較する推計 残差の分析を行うと, この地点の個性とでもいうべき要 因がかなり大きく働いていることがわかる.

推計值が観測值を大幅に下回る（推計残差の標準偏差 である 0.3 以上）地点は， $01,13,25,33,38,46,54,59$ (図一1参照)の 8 地点あり, 逆に上回るものは, 10, 11, $32,40,49$ の 5 地点である. これらの地点に共通の説明 を見出すのは困難であるが，一般に過小推計をしている 8 地点には, 市役所や幼稚園あるいは祠, 広場, 清流に 沿った並木など，扔のおの種類は異なっているが人々を 引きつける何物かがあることがわかる．これに対し，過 大推計になるところは，極めて閉塞的な路地の場合と， 上記の過小推計点と競合する位置にあるものに別れるよ うである。

このようにここに揚げた経路選択モデルに推計誤差 を持たらす要因は，一般化の難しい，いわ沛るアメニテ ィーとか個性といった範畴のものであるといえるようで ある.したがって，さらにモデルの改良を進めるには， これらの要因をいかにして計量化していくかが問題とな ってくるようである.

\section{（2）迂回距離の分布}

実際の歩行経路が最短経路から迁回する長さについて は迁回長と迁回率について分析する.

まず, 850 件の調査デー夕について観測された経路に 沿って実際の距離を計算し, これと最短経路長との差を 求め, これを迂回長とする. さらに, この迂回長を最短 経路長で除したものを迁回率とする. この計算の過程で データの中に起終点が一致する回遊トリップや, 迁回長 や迂回率が過大となるもの $(700 \mathrm{~m}$ 以上，500\% 以上計 13 件)を不良データとして除外した. したがって, 以 下の分析に用いるデータは 725 件である.

この迁回長と迂回率の累積分布図を示したものが 図一 7である. 全データの平均值 (標準偏差) は迂回長 57.76 $\mathrm{m}(111.84 \mathrm{~m})$, 迁回率 $18.6 \%$ (50.96\%) であるが, こ のような下方硬直型の分布において平均值は意味を持た ない. ちなみに, 度数分布表において最も度数の多いの は迁回長 $0 \mathrm{~m}$ であって, 全体の $33.8 \%$ に達している.

いま，累積分布曲線の勾配が急に緩やかになる $85 \%$ を持って迂回の限度を定義すれば, 迁回長で $100 \mathrm{~m}$, 迁 回率で $20 \%$ となる.また，95\% の点を限度とすれば $250 \mathrm{~m}, 100 \%$ となる. 迂回長の限度を絶対距離と率と のどちらで定義するかは, 一概に決め難いところである が, この曲線を比較するならば, 迂回率の方が急激に曲 率の変化が表われて抢り, 定義に用いるについてはより 妥当であるように思われる. また, 迁回長の実距離に対 する相関図では, 相関係数 $r=0.41$ (データ 481 件)を 得ており, 分布の上界は明膫にトリップ長の増加に伴。 て迂回長が増加することを示している. そこで，ここで は迂回長の上限は迂回率 20\%（85\% 点）を採っておく

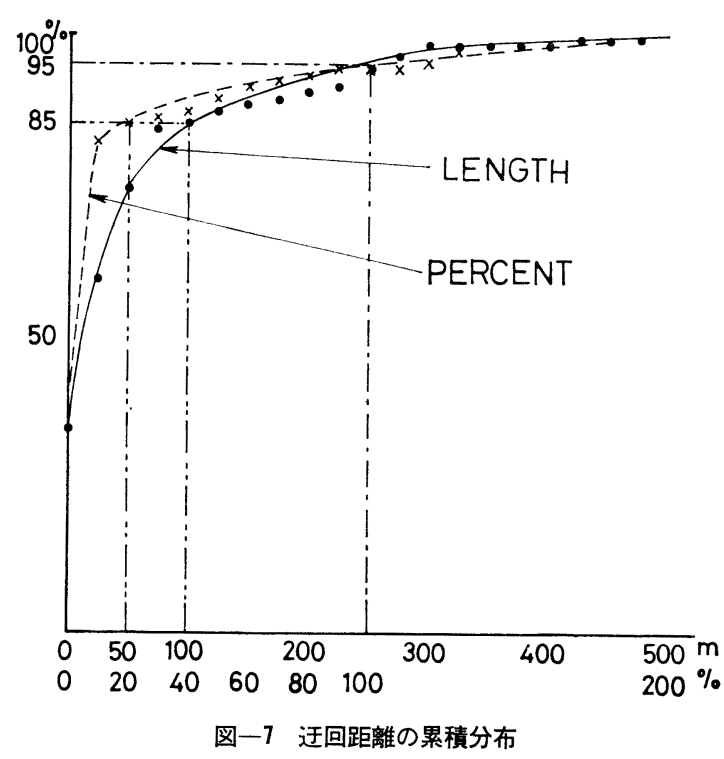




\section{表一8 年令性別平均迁回長}

\begin{tabular}{|c|c|c|c|c|c|}
\hline & \multicolumn{2}{|c|}{ 迁 回 長 } & \multicolumn{2}{|c|}{ 迁 回 率 } & \multirow{2}{*}{ データ数 } \\
\hline & $\bar{X}(\mathrm{~m})$ & C.V.(\%) & $\bar{X}(\%)$ & $\mid$ C.V.(\%) & \\
\hline 中学 生 & 63 & 246 & 13.1 & 249 & 31 \\
\hline 高 校 生 & 111 & 156 & 25.7 & 164 & 38 \\
\hline 青 年 (男) & 121 & 96 & 29.6 & 115 & 34 \\
\hline " (女) & 101 & 137 & 37.3 & 216 & 83 \\
\hline 壮 年 (男) & 68 & 130 & 26.6 & 243 & 52 \\
\hline " (女) & 84 & 148 & 27.3 & 218 & 152 \\
\hline 老 年 (男) & 86 & 132 & 35.8 & 213 & 29 \\
\hline " (女) & 64 & 170 & 21.0 & 235 & 59 \\
\hline
\end{tabular}

ことにする。

次に，この迁回長分布を年令性別にみてみると，各層 の平均值および層内の変動係数は表一8のようになる. 迁回長の平均值は高校生・青年男女のグループと壮・老 年男女に中学生を加えたグループに明確に 分かれてい て，前者は 100 120 $\mathrm{m}$ の值を示すのに対し，後者は 60 〜86 $\mathrm{m}$ という值を示している. もちろん, 各層ごとに 平均值は異なっているが，同表に示したように各層内デ 一夕の変動係数が大きいので, この 8 層分類による層間 格差は有意ではない。しかし，今これを上述の 2 グルー プにま上めて分散分析を行うと, 非青年グループ（中学 生を含む）は $77 \mathrm{~m}$, 青年グループは $108 \mathrm{~m}$ の平均值を 示し， $F$ 值は 5.98 であって，有意水準 $2.5 \%$ で有意な 格差が認定される。

一方, 同様の層による迁回率の差は表一8に併せ示し たが，変動係数の大きさをも考慮すれば，層間の一定の 格差傾向を見出すことは，ほとんど不可能である.

このよらに, 歩行者交通における最短経路からの迁回 については，その率は年令性別によって差はみられない のであるが，一般に高校生や青年の徒歩トリップ長の長 いことを反映して，迂回長法この畨で長くなることがわ かる。

\section{（3）地点別の平均迁回長}

さて, 各観測点ごとに, 通過するトリップの迁回長お よび迁回率を平均し，地点別平均迁回長および迂回率を 計算することができる。これをヒストグラムに表わすと 図一8のようになる.このように，地点によって，平均 迁回長にはかなりの差があることがみられる.そこで, 各 地点の商店数と平均迁回長との関係を調べてみると 表 一9のようになる。これによると, 迁回長が $80 \mathrm{~m}$ から $140 \mathrm{~m}$ といら最もデータの多い部分では, 商店数の多い ところほど平均迁回長が長いものが多く, 経路決定モデ ルにおいて商店数が大きく寄与していたことに対応して いる.しかし， $80 \mathrm{~m}$ 以下と $140 \mathrm{~m}$ 以上の平均迂回長を 持つ地点は必ずしもこの法則に従っていない．これらの 地点のらち, 商店数が 0 でありながら平均迁回長が 140 $\mathrm{m}$ を越えている4 地点を見てみると次のようなことがわ

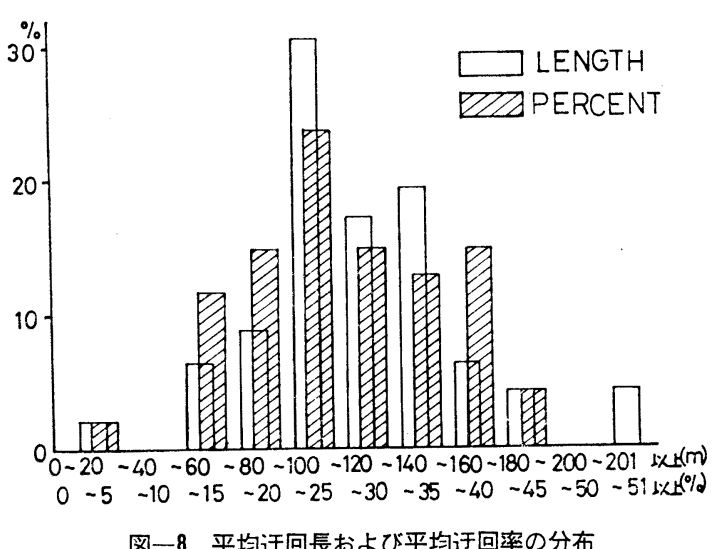

表一9 迂回長之商店数の関係

\begin{tabular}{c|c|c|c|c|c}
\hline \multirow{2}{*}{$\begin{array}{c}\text { 平均迁回長 } \\
(\mathrm{m})\end{array}$} & \multicolumn{4}{|c|}{ 商 店 数 $($ 軒 $/ 100 \mathrm{~m})$} & \multirow{2}{*}{ TOTAL } \\
\cline { 2 - 5 } & 0 & 1 & $2 \sim 4$ & 5 以上 & \\
\hline $0 \sim 80$ & 2 & 0 & $(3)$ & $(3)$ & 8 \\
$81 \sim 100$ & 5 & 5 & 2 & 2 & 14 \\
$101 \sim 120$ & 3 & 1 & 2 & 0 & 6 \\
$121 \sim 140$ & 2 & 0 & 4 & 5 & 11 \\
$141 \sim$ & $(4)$ & 1 & 1 & 1 & 7 \\
\hline TOTAL & 16 & 7 & 12 & 11 & 46 \\
\hline
\end{tabular}

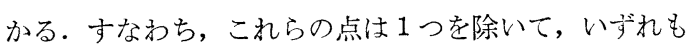
商店街への進入ルート上にあり, そのらちの 1 つは市役 所の前である. このように, 商店数を当該地点の前後 $100 \mathrm{~m}$ について数えて, これを商店街の指標とすること の不十分さが，ここに現われているとみることができ る. 歩行者の経路をひきつける要素は, 単に商店の数の みではなくて, その他, そのトリップの目的地ではなく とも, 良く目的施設となりらる親しみのある施設群であ り，なおかつ，それらへの接近路であるということがで きよう。

\section{6. 結 語}

歩行者が通行経路を決定するにあたって, 歩行者自身 の街路についての評価と実際の選択行動および客観的な 街路環境条件との三者の間にどのような相互関係がある かを把握するのが本論の目的であった，研究の結果は, 歩行者の街路評価メカニズムについてはかなりの把握が できたが, 街路選択行動の説明ははなはだ不十分な段階 に留まっている. しかし, 所期の目的の多くの部分法達 成されたのであって，いまそれをまとめて及れば次のよ うになる。

（1）歩行者は自動車交通量が少なく，視界に薣木な ど緑の多いほど，良い道路だと見なしている，また，歩 道の存在は, 自動車交通量の影響を緩和するが，これは 簡易構造の歩道では意味がない. 
（2）ところが，歩行者は必ずしも自己の良いと評価 した経路を歩いてはいず, 多少環境は悪くとも, 商店が 多く䯳やかで幅の広い街路を選択している.

（3）このように，歩行者は必ずしも最短経路を歩く のでもない，上述のような䀼やかな街路を求めて，かな りの迁回をも厭わないのであるが, その迁回の限度は, おおむねトリップ長の $20 \%$ である.

このような実体であるから，今後の歩行者交通空間の 整備にあたっては, 商店街や公共施設のある街路の歩行 者化 (pedestrianization) を進めていくことが必要であ る.この場合に，歩道はマーキングやガードレールのよ らな応急措置では不十分なこと. 道路環境の向上策とし ては, 天空率を向上させるよりは植樹や花壇などの環境 緑化がむしろ有効なこと.また，広場や祠などオープン スペースと歩行者路との結合がことのほか重要であるこ となど，本研究より得られた知見が役に立つであろう。

本研究の遂行にあたっては, 中部工業大学土木工学科 計画研究室の学生諸君の協力を得た. 特に技術員 小川 成夫君の協力は重要であった. また, データ収集にあた って, 愛知県交通対策室, 犬山市交通企画課, (株) E \&
S の協力をいただいた.ここに厚く感謝する.

なお, データ処理は中部工大計算センターのシステム を用いたほか, 数量化理論の分析にあたっては名古屋大 学大型計算センターで FACOM アプリケーションプロ グラムを用いた。

\section{参考文 献}

1) G. Dietrich : Pedestrian paths through a uniform environment, Town Planning Review, Apr. 1971.

2）今西芳一・越 正毅：歩行者の経路選択特性任関する研 究, 土木学会第 30 回年次学術講演会講演概要集第 4 部, 1975.10 .

3）深海隆恒：歩行者の流れについて，月刊交通 (整察仃編)， 1975.11.

4）高橋国一郎ほか：AASHO 道路試験，日本セメント技術 協会, 1966 .

5) OECD 編, 宮崎 正訳：楽しく歩ける街, PARCO 出版 局, 1975.10 .

6）愛知県企画部交通対策室：都市における生活空間再開発 に関する調查研究報告書, 1975.3 .

7）松本嘉司：土木解析法 (1)，技報堂，1971.11.

8）奥野忠一ほか：多変量解析法，日科技連，1971.10.

9）林知已夫ほか：市場調査の計画と実際，日刊工業新聞社.

10) FACOM マニニアルフプリケーションプログラム QUANTAS.

(1976.5.24 - 受付) 